\title{
An Evaluation of Technological Competences and Technological Tools Usage by Primary School Teachers During COVID-19 Lockdown in Cameroon
}

\author{
Kenneth Yuomeyse \\ Faculty of education, University of Yaoundé 1
}

\author{
Henri Rodrigue Njengoué Ngamaleu, PhD \\ Faculty of education, University of Yaoundé 1
}

\begin{abstract}
The aim of this study is to investigate technological competences and technological tools usage by primary school teachers. The inability of primary school teachers to substitute traditional teaching methods with modern technological tools and applications during COVID-19 motivated the researchers to carry out this study. The study made use of a survey research design. Technology implementation and computer use for instructional teachers sub scales were used to collect data. Related literature was reviewed based on skills and knowledge of teachers and the various technologies used for instruction. The samples were 398 teachers who are teaching using ICT and the simple random sampling method was employed to select these respondents. Data was collected from teacher-respondents using tables, percentages, charts, mean, standard deviations and one sample t-test. The results showed an average level of technological competences possess by primary school teachers and types of technological tools used for teaching and learning. These results indicate that primary school educators and instructors lack the competences to install software on their computers and faced difficulties in using more advanced technologies. The study strongly recommends effective in-service training for teachers, easy access and connection to network services as well as the provision of technical assistance to schools. This will enable teachers to effectively acquire skills and knowledge for technology integration in education. Primary schools and teachers should also be equipped with modern technologies especially during this period of COVID-19.
\end{abstract}

Keywords:- Evaluation, Technological Competences, Technological Tools, Primary School Teachers, Cameroon.

\section{INTRODUCTION}

The use of Information and Communication Technology is affecting all aspects of life including teaching and learning in schools. ICT contributes to universal and equal access to education and the transmission of knowledge between teachers and learners. ICT in teaching and learning concerns incorporation of computers into routine classroom teaching process through communication (Ghavifekr \& Rosdy, 2015). While preparing learners for the new digital era, instructors are the main players in using technology in the classroom. According to Arnseth \& Hatlevik (2012), ICT has the capability to provide dynamic and proactive environment for teaching and learning. The purpose of integrating ICT in education is to improve and add the quality, easy access and cost-efficiency teaching to students in the classroom and on distance. ICT integration provide benefits from networking the teaching and learning environments to face the challenges of recent globalization (Albirini, 2006). When learners are used to Information and Communication Technology, they learn well in the technology-based settings (Ghavifekr \& Rosdy, 2015). With the help of ICT components and elements, the integration of technology in the classroom is important because it lead to more effective learning (Jamieson-Procter et al., 2013). The integration of technology in education enriches the programme study in schools because it provides access to much information. ICT encourages effective communication and participation with one another in educational environments.

In Cameroon primary schools, insufficient training on the integration of ICT in classroom teaching and learning has been given to teachers to improve their skills, knowledge and competences since 2001 when ICT was introduced in schools (Nkwenti, 2015). The ICT syllabuses and National Sequential Schemes of work was published and available to Nursery and Primary schools as well as Teacher Training institution in 2008 (Ngajie \& Ngo, 2016). According to Mbangwana (2008), the national book commission wrote and adopted textbooks to facilitate ICT teaching in schools. They also drafted strategy for implementation of ICT national policy in Nursery and Primary schools in 2007 that was available and applicable between 2007 to 2015 (Ngajie \& Ngo, 2016). Since the outbreak of coronavirus (COVID-19) pandemic in Cameroon and other African countries, education has changed dramatically, with the distinctive increase of distance learning where the teaching and learning takes place remotely on digital platforms. Teachers in primary schools need to effectively teach their learners through distance learning platforms. Teachers face difficulties to change their traditional teaching methods with modern technological tools and facilities. They have insufficient competences to build e-learning platforms and use technological tools application to facilitate the teaching and learning process especially during COVID-19. This research provides insight in better understanding the ICT skills, competences and technological tools usage among primary school teachers in Cameroon. 


\section{A. Technological skills and competences}

For effective technology integration to take place, teachers need to have sufficient skills, beliefs and knowledge to take the benefit of technology in instruction (Chen, Looi \& Chen, 2009). Technology integration in the teaching and learning is a complicated, dynamic and difficult development (Binghimlas, 2009; Koehler, Mishra \& Yahya, 2007; Schoepp, 2005, Birisci \& Kul, 2019). According to studies carried out by researchers, effective integration of technology in education cannot be obtained if technology integration development is not better assimilated by classroom instructors (Ertmer, 2005; Hew \& Brush, 2007, Birisci \& Kul, 2019). An important component of training programs for teachers is that they should gain competences, skills and knowledge concerning the use of current technology integration within the process of their professional enhancement and development (Chai et al., 2011, Birisci \& Kul, 2019). According to Hsu (2010), technology integration is not seen as the use of computer as recent researchers have pointed out that integrating ICT during instruction needs competences and that are not similar from using computers (Angeli \& Valanides, 2009). The teachers in schools need specific competence and knowledge for technology integration in education (Hsu, 2010). The integration of technology during instruction implies taking into consideration students' needs, the school programme, accessible technology, lesson planning, media designing issues and joining them into a practice which will complement pupils learning (Hennessy, Ruthven, \& Brindley, 2005).

The readiness and competences of teachers in ICT usage play an important role in education as they need adequate ICT skills to integrate the technology and to have confident in using ICT in classroom environment (Ghavifekr \& Rosdy, 2015). According to Karatas (2014) and Polly, Mims, Shepherd \& Inan (2010), the courses given to teachers related to technology with the purpose of successful integration of technology in the teaching and learning process is not enough to prepare them for instruction. The recent graduated educators are people who do not have enough skill levels to use technology in education (Kurz \& Middleton, 2006). The role of teachers in school programme implementation needs unquestionable knowledge to integrate the content effectively that need to be taught (UNESCO, 2015; Sekoaila et al., 2016). Igbo \& Imo (2017), point out that like other subjects that are taught by teachers, ICT integration needs teachers to have different skills to deal with all difficulties affecting technology integration into teaching and learning.

They are abundant technologies that capture, process, store and transmit digital information that are hardwarebased equipment like computers, game consoles, smart phones, audio and video players, and software applications like web-based applications, wikis, blogs, chat sites socialnetworking sites, (Sibusisiwe \& Scott 2017). Groff (2013), adds that simulations, handheld and tablet computing, video and image sharing, games and gamification, scanners, digital cameras, augmented virtual reality environments, and comfortable technologies as evolving computer technologies accessible for teaching and learning (Sibusisiwe \& Scott, 2017). Shaw's (2017) on his part, describes emerging technologies as a constellation of digital technologies which are computerized and networked, mobile, interactive and social and covers a lot of technologies, channels, media and platforms. Almara'beh et al, (2015), point out that digital technologies, like videopublishing, photo-sharing and map-making programs can be applied in education for learners to have opportunities and chances by demonstrating the mastery of ideas and concepts. This will help reinforce learners' skills and competences in literacy and enable them to create their own learning content. The teaching and learning process are more goals oriented, flexible, participatory and is not affected by distance and learners are tilted toward individual style of learning. There is a lot of collaboration among teachers and learners in the multimedia environments (Almara'beh et al, 2015). Digital media enhances the importance of activities in the science classroom and technological tools and applications like social networking, blogs podcasts, audio and streaming video can be explored by the teachers to engage pupils to reinforce media literacy technological tools and master the various concepts in science (Almara'beh et al, 2015)

\section{B. Technological tools and applications}

According to Eady \& Lockyer (2013), schools are now equipped with computers and interactive whiteboards and are connected to one another all over the world at a higher speed than was the case in the past. Mobile technologies like Laptop computers, smartphones and tablet devices in education have become part of the teaching and learning. Babateen (2011), believes that the use simulations and virtual reality in educational multimedia environment in teaching and students learning is increasing and has demonstrated to be effective instructional tools to in teaching difficult disciplines science (Oluwole, 2018). According to Vélez-Agosto \& Rivas-Vélez (2018), students who play video games in the classrooms assimilate rules and concepts and as a rhetorical persuasion process when they play, because they involve in an important process that help them to advance in the game learning (Rivas, 2012). The use of Videogames help to solve the problems that result from the educational system approaches because it adds more meaning and impetus to the learning environment (Vélez-Agosto \& Rivas-Vélez, 2018) principles can be demonstrated with the use of simulations and they provide experiential learning which gives both learners and their teachers opportunities to change from the lecture method of teaching in a traditional classroom to supportive lecture-related technologies (Sottile \& Brozik, 2004). Simulations help in the learning process as they transfer learning based on concepts to full application and the powerful relationship between perceived realism and perceived involvement of the simulation to teaching and learning (Brozik and Zapalska, 2002b; Brozik and Zapalska, 2003, Sottile \& Brozik, 2004). 
Mobile devices are now part of students and teachers' daily life because they shape their habits. With the involving habits, educational institutions are reshaping their educational systems to meet the aspirations of both learners and their educators as they integrate the various technologies into classrooms practices (White \& Manton, 2011). Olawale (2017), believes mobile technologies have revolutionized the world and tablets, have gained quickly gained grounds in the various age group and in public places. It is not easy to imagine the contributions of mobile devices when they are used in education. Kakoty et al., (2011), add that mobile devices, and such as smartphones and tablets are of recent becoming important and indispensable in the teaching and learning environments (Olawale, 2017). Students find information, knowledge, skills for recent information concerning the activities of the world and research from the internet (Chhachhar et al, 2013). Web tools such as search engines, shared whiteboards blogs, and social networks supply pedagogy and applications to enforce teaching and learning as well as support more participatory and collaborative ways of learning (Puvaneswary \& Yen Siew, 2018, p.67). According to Almara'beh et al, (2015) some multimedia software from Sony Creative Software can incorporate audio, video and music, into existing school programme include the following:

$>$ Group video report that enable team building and provide experience with modern technology. From three to five learners can be assigned to a team and each team choose a topic based on the short video they want to make

$>$ Enhancing the websites application in school using a streaming video content where learners can create a video round the school complete with subtitles, host or narrator.

$>$ Lesson on language through video language lesson that helps in fast learning.

$>$ Slideshow presentation which can be used to teach any discipline and are easily created with Sony software video editing to promote lessons learning.

$>$ Multimedia portfolios which present learners work in an original manner where they can produce a slideshow indicating their excellent work.

$>$ Podcast communication method that allow any learner to produce audio files and put the files on the internet so that other learners can download and learn.

$>$ Conversion of lessons to MP3 where learners can often listen to them.

Lonn \& Teasley (2009), believe that web-based systems like Learning Management Systems facilitates submissions and corrections of assignments, online communication and sharing of materials between instructors and learners. Almrashdeh et al. (2011), on their part opine that the Learning Management System software application can be used to design, administer and access individual process of learning. Xingeng \& Jianxiang (2012), believe that PowerPoint is important in individual instruction where animation, flexible models and differences of color can better facilitate illustration of the main concepts. There should be retention of complex graphics, figures and animations by learners and important points should be placed on online side by instructors and avoid the use of sentences that are long. The instructor should also use phrase and key words, correct front size and graphs. color and background and avoid animation that can caused distraction to learners (Xingeng \& Jianxiang, 2012).

\section{Objectives of the study}

The two objectives guiding the study include the following:

$>$ To examine technological skills and competences possess by teachers in primary schools during COVID19.

$>$ To investigate the types of technological tools usage in teaching and learning during COVID-19 in primary schools.

\section{METHODOLOGY}

\section{$>$ Participants}

The respondents for this research work were 398 teachers selected from anglophone and francophone primary schools both private and public schools in Mfoundi Division, Centre region of Cameroon. This was done using the simple random sampling method where the population members were assigned unique numbers, placed in a container, and well stirred. The numbers were then drawn from the container and the process were repeated until the required sample numbers were obtained.

There were 146 males with percentage $36.7 \%$ and 252 females with a percentage of $63.3 \%$ participants included in the research process. Their ages ranges between 21 to 56 years old and 157 contract teachers (39.4\%), 193 grade one teachers $(48.5 \%), 9$ senior grade one $(2.3 \%)$ and 38 untrained teachers $(9.5 \%)$. There were 109 participants from public schools $(27.4 \%)$ and 289 from private schools (72.6\%). 78 participants from class one (19.6\%), 58 from class two (14.6\%), 66 from class three $(16.6 \%), 65$ from class four (16.3\%), 64 from class five $(16.1 \%)$ and 67 from class six (16.8). The number of learners in these classes ranges from 03 to 150 and 216 teacher respondents were from the anglophone subsystem (54.3\%) and 182 from francophone subsystem $(45.7 \%)$ of education. There were 78 participants who were holders of ordinary level certificate (19.6\%), 236 holders of advanced level certificate $(59.3 \%), 75$ holders of bachelor of education (18.8\%), 9 holders of master of education $(2.3 \%)$ and their experience in the teaching field ranges from 1 to 30 years.

\section{$>$ Material and design}

Data was collected from the respondents using a questionnaire in a survey research design. Technological competences were assessed using computer use for instructional teachers adopted and from Ghavifekr et al (2014) sub scale (I have knowledge on the functions of a computers, I can repair a computer without any difficulties or assistance...). A four -point Likert scale format was adopted to measure respondents' responses for every area of the questionnaire scale (strongly disagree $=1$, disagree $=2$, agree $=3$ and strongly agree =4). Technology tools 
applications and level of usage was measured using technology implementation sub scale (CD player, LCD projector, digital camera....) adopted from Matthew Woods (2015) and the scale adopted a six-point Likert scale format (6=Regularly, 5= Frequently,4 = Occasionally, 3=Seldom 2 $=$ Rarely, $1=$ Never $)$.

Both the questionnaire face validity and content validity were determined and appraised. Test-retest reliability was used to determined reliability of the research instruments. This was done to evaluate factors of measurement error by reiterating the measuring procedure on the equal subjects under same atmosphere to compare observations. The questionnaire was tested to a group of 30 teachers and after two weeks, the same questionnaire was still conducted to the same group of teachers. Their responses were correlated, and the results evaluated indicating a high degree of consistency. The Cronbach's reliability investigation was applied to test internal consistency of the study variables. The reliability was evaluated and assessed by Cronbach's alpha coefficient of around 0.8 .
For ethical issues, the required permissions were taken from the primary school inspectors and headteachers of the respective schools. The teachers' respondents were previously informed before the study and their privacy respected. They were not required to identify their names or give personal information concerning them. The respondents responded to the questionnaire in the classroom setting where it took them 10-15 minutes to finish. This was a paper-pencil based format questionnaire.

\section{Analysis of data \\ Version 25.0 Windows of the Statistical Package for Social Sciences (SPSS) was used to analysed data. To arrange, organise and give full meaning to our data, statistical tools such descriptive statistics, percentage, charts, mean, standard deviation and independent t-test was used. This was done to compare the mean value and evaluate whether the population sample have different mean values.}

\section{RESULTS}

\section{Technological skills and competences}

\begin{tabular}{|c|c|c|}
\hline Items & Mean & Std. Deviation \\
\hline I have knowledge on the functions of a computers & 2.90 & .753 \\
\hline I can repair a computer without any difficulties or assistance & 1.60 & .776 \\
\hline I can install software applications in the computer & 2.00 & .989 \\
\hline I search instructional materials for my learners from the Internet & 2.93 & .871 \\
\hline I prepare lesson plans for my learners on the computer & 2.38 & .990 \\
\hline I can create teaching and learning materials from the computer & 2.40 & .947 \\
\hline I can design and create a website for learning on the computer & 2.07 & .950 \\
\hline I produce notes for my learners using the Internet & 2.65 & .978 \\
\hline I search questions for my learners using the Internet & 2.49 & .979 \\
\hline I teach consistently in the classroom with the computer & 2.09 & .931 \\
\hline I frequently look for recent information from the Internet & 2.93 & .937 \\
\hline I make use of Internet in the computer laboratory with my learners & 2.27 & .998 \\
\hline I teach learners on how to obtain facts or knowledge from the Internet & 2.60 & .954 \\
\hline I work on the Internet for private and individual use & 3.26 & .819 \\
\hline
\end{tabular}

Table 1:- Respondent opinions according to technological skills and competences.

Table 1 above presents respondents' opinions on level of technology skills and competences. It can be observed that the highest score is where primary school teachers work on the Internet for their individual and private use (M $=3.26 ; \mathrm{SD}=0.819 ; \mathrm{t}(396)=18.409 ; \mathrm{p}<.001)$, constantly look for frequent information from the Internet and look for instructional materials on the Internet for their learners (M $=2.93 ; \mathrm{SD}=0.937 ; \mathrm{t}(397)=9.090 ; \mathrm{p}<.001)$, have knowledge on the functions of a computer $(\mathrm{M}=2.90 ; \mathrm{SD}=$ 0.753 ; $\mathrm{t}(397)=10.649 ; \mathrm{p}<.001)$. The lowest opinions are when they can repair their own computer $(\mathrm{M}=1.60$; $\mathrm{SD}=$ $0.776 ; \mathrm{t}(397)=-23.050 ; \mathrm{p}<.001)$, install software on their own $(\mathrm{M}=2.00 ; \mathrm{SD}=0.989 ; \mathrm{t}(397)=-10.090 ; \mathrm{p}<.001)$, construct a learning website $(\mathrm{M}=2.07 ; \mathrm{SD}=0.950 ; \mathrm{t}$ (397) $=-9.128 ; \mathrm{p}<.001)$ and always use the computer in their classrooms $(\mathrm{M}=2.09 ; \mathrm{SD}=0.931 ; \mathrm{t}(395)=-8.740 ; \mathrm{p}<$ $.001)$.

From the group statistics on the technological competences and Independent sample t- test, the results indicate an average $(\mathrm{M}=34.49 ; \mathrm{SD}=7.37 ; t(390)=-1.373$, $p=.171$ ), level of technological competences and knowledge possess by primary school teachers. 
ISSN No:-2456-2165

\section{Technological tools and applications}

\begin{tabular}{|c|c|c|c|}
\hline No & Items & Mean & Standard deviation \\
\hline 1 & CD player & 2.49 & 1.678 \\
\hline 2 & LCD projector & 1.53 & 1.062 \\
\hline 3 & Digital camera & 2.93 & 1.893 \\
\hline 4 & Calculators/Graphing & 3.65 & 2.011 \\
\hline 5 & Laptops & 3.17 & 1.932 \\
\hline 6 & I pad & 1.83 & 1.506 \\
\hline 7 & DVD Player & 2.38 & 1.784 \\
\hline 8 & Web Camera & 1.69 & 1.305 \\
\hline 9 & Smart board & 1.78 & 1.400 \\
\hline 10 & Computer & 3.43 & 1.871 \\
\hline 11 & Video camera & 2.89 & 1.869 \\
\hline 12 & Headphones & 2.77 & 1.987 \\
\hline 13 & Apple TV & 1.74 & 1.502 \\
\hline 14 & TV & 3.27 & 2.237 \\
\hline 15 & Smart phone & 3.71 & 2.246 \\
\hline 16 & Overhead projector & 1.57 & 1.180 \\
\hline 17 & Document camera & 1.52 & 1.180 \\
\hline 18 & I Pods & 1.27 & .867 \\
\hline 19 & VCR Player & 1.046 \\
\hline
\end{tabular}

Table 2:- Technological tools and usage in the classroom

Table 2 above presents the distribution of respondents' opinions on technological tools and level of usage in the classroom. It can be observed that the highest primary school teachers use smartphones $(\mathrm{M}=3.71 ; \mathrm{SD}=$ $2.25 ; \mathrm{t}(396)=1.866 ; \mathrm{p}=.063)$, Calculators/Graphing $(\mathrm{M}$ $=3.65 ; \mathrm{SD}=2.01 ; \mathrm{t}(396)=1.510 ; \mathrm{p}=.132)$, Computer $(\mathrm{M}$ $=3.43 ; \mathrm{SD}=1.87 ; \mathrm{t}(397)=-750 ; \mathrm{p}=.454), \mathrm{TV}(\mathrm{M}=3.27$; $\mathrm{SD}=2.24 ; \mathrm{t}(397)=-2.084 ; \mathrm{p}=.038)$, Laptops $(\mathrm{M}=3.17$; $\mathrm{SD}=1.93 ; \mathrm{t}(397)=-3.425 ; \mathrm{p}<.001)$, digital camera $(\mathrm{M}=$ 2.93; $\mathrm{SD}=1.89 ; \mathrm{t}(395)=-5.974 ; \mathrm{p}<.001)$ and video camera $(\mathrm{M}=2.89 ; \mathrm{SD}=1.87 ; \mathrm{t}(396)=-6.458 ; \mathrm{p}<.001)$. The least and lowest number of respondents declare that they use I pods $(\mathrm{M}=1.27$; $\mathrm{SD}=0.87$; $(394)=-51.015 ; \mathrm{p}$ $<.001)$, VCR player $(\mathrm{M}=1.43 ; \mathrm{SD}=1.05 ; \mathrm{t}(394)=-$ $39.281 ; \mathrm{p}<.001$, documented camera $(\mathrm{M}=1.52 ; \mathrm{SD}=$ $1.18 ; \mathrm{t}(396)=-33.419 ; \mathrm{p}<.001)$, LCD projector $(\mathrm{M}=$ $1.53 ; \mathrm{SD}=1.07 ; \mathrm{t}(396)=-37.013 ; \mathrm{p}<.001)$, Overhead projector $(\mathrm{M}=1.57 ; \mathrm{SD}=1.18 ; \mathrm{t}(394)=-32.545 ; \mathrm{p}<$ $.001)$. This result indicates average technological tools and how often they are used in the process of teaching and learning. The results indicated that $94.2 \%$ of primary school educators use other technological tools in less than a week, $00.8 \%$ at least a week with a total of $95.0 \%$. This indicate that few teachers use other technological tools during instructions and pupils learning.

\section{DISCUSSIONS}

The research investigations indicate an average technological skills and competences possess by teachers in primary schools. This implies that technology integration into teaching and learning needs the acquisition of different level of technological skills and competences. This will enable teachers in primary schools to handle the difficulties related to technology integration in the classroom environments. Lack of competency and mastery of ICT skills to repair computers, install software, construct learning websites and frequent use of computers impede teacher to effectively use ICT in the teaching learning process during COVID- 19 in Cameroon. Findings reveal that teachers work on the internet for their individual and private use, search for teaching learning materials and recent information form the Internet. They also have knowledge of computers and its functions. Primary school teachers use TV, Calculators/Graphing, Computer, Apple TV, Laptops frequently and few of them often use other technologies during the process of teaching and learning. Teachers in primary schools lack the abilities and competences to use Document camera, I Pods, LCD projector, Overhead projector, Web Camera and VCR Player in the teaching and learning process during COVID19. 
Teachers in primary schools need different range of communication and technical competences. These competences and skills include web page authoring, word processing, chat rooms and various types of technologies like the compression and decompression of files and File Transfer Protocol (FTP), compress. They need skills for individual use of technology during teaching, mastering of different teaching and learning paradigms that use technology during teaching. They need enough skills and competence for private use of technology as mind tools, competences and skills for ICT usage for teaching, competence to master evaluation paradigms that use of technology in teaching. Teachers should attend ICT course and training acquire competences to understand the policies and dimensions of technology usage for teaching and learning.

Primary school teachers should frequently integrate technological tools such hardware devices and software applications in the teaching and learning process. The hardware devices that they can integrate into teaching include computers and their peripheries and mobile devices like video and audio players, smartphones, tablets and game consoles. The software- applications that teachers can integrate into the teaching and learning include wed based applications like social-networking sites, blogs, wikis and chat sites. They should also make use of simulations, video and image sharing, power point presentations, iPods, handheld and tablet computers, Smart boards, headphones, digital cameras, virtual settings, scanners, augmented reality and other digital technologies available for teaching and learning. The ministry of basic education and other education stake holders in Cameroon should provide schools with multimedia centres, network connection and accessibility, hardware and software applications, technical support, effective professional development and in-service training technological development programmes to enable teachers acquired skills and competences on technology usage in the teaching and learning during COVID-19.

\section{CONCLUSION}

The introduction of emerging technologies in the teaching and learning environments require a lot of technological competences and technological equipment. Educators and researchers must have a good grasp of digital technologies and how to integrate them in the teaching and learning environments. Teachers' continual professional ICT training and development should also be taken into consideration when designing ICT policy. Teaching and learning environments that are full of technologies provide better improvements of organization, collaboration and problem-solving competences. There is cooperative learning in technological learning settings and the integration of technology in these environments facilitate interaction between teachers and learners. Learners learn by doing, get feedback from their instructors and continuously construct new knowledge and restructure their learning. Technology integration in education can facilitate active learning through which children search, manage, assess and make use of information they obtained for digital technologies. The provision of information resources to learners, provide them the opportunity to new discoveries that support their learning. The children can discuss their discoveries and share them with their teachers and classmates through software applications and presentations either in the classroom or at a distance.

\section{REFERENCES}

[1]. Adams, S. T. (2005). A strategy for technology training as part of a master's program conducted at a school site. Journal of Technology and Teacher Education, 13(3), 493-514.

[2]. Albirini, A. (2006). Teachers' attitudes toward information and communication technologies: The case of Syrian EFL teachers. Computers \& Education, 47(4), 373-398.

[3]. Almara'beh, H., Ehab F. A., \& Amjad, S. (2015). The Effectiveness of multimedia learning tools in education. International Journal of Advanced Research in Computer Science and Software Engineering, 5, (12), 761-764

[4]. Almrashdeh, I.A., Sahari, N., Zin, N.A.M., \& Alsmadi, M. (2011). Distance learning management system requirements from student's perspective. Journal of Theoretical and Applied Information Technology, 24(1), 17-27.

[5]. Angeli, C. \& Valanides, N. (2009). Epistemological and methodological issues for the conceptualization, development, and assessment of ICT-TPCK: Advances in technological pedagogical content knowledge (TPCK). Computers \& Education, 52(1),

154-168 http://dx.doi.org/10.1016/j.compedu.2008.07.006

[6]. Arnseth, C.H. \& Hatlevik, E.O. (2012). ICT, Teaching and Leadership: How do Teachers Experience the Importance of ICT-Supportive School Leaders? Nordic Journal of Digital Literacy, 7(1), 55-69.

[7]. Binghimlas, K. A. (2009). Barriers to the successful integration of ICT in teaching and learning: A review of literature. Eurasia Journal of Mathematics, Science and Technology Education, 5(3), 235-245.

[8]. Birisci, S. \& Kul, U. (2019). Predictors of technology integration self-efficacy beliefs of preservice teachers. Contemporary Educational Technology, 10(1), 75-93.

[9]. Brozik, D. and Zapalska, A. (2002b). The portfolio game. Simulation and Gaming, 33 (2) 243256.

[10]. Brozik, D. and Zapalska, A. (2003). Experimental game: Auction! Academy of Educational Leadership Journal, 7 (2) 93-103.

[11]. Brush, T., Igoe, A., Brinkerhoff, J., Glazewski, K. \& et. al. (2001). Lessons from the field: Integrating technology into preservice teacher education. Journal of Computing in Teacher Education, 17(4), 16-20.

[12]. Chai, C.S., Koh, J.H.L., Tsai, C.C. \& L.L.W. Tan. (2011). Modeling primary school pre-service teachers' technological pedagogical content knowledge (TPACK) for meaningful learning with information and communication technology (ICT). Computers \& Education, 57, 1184-1193. 
[13]. Chen, F., Looi, C., \& Chen, W. (2009). Integrating technology in the classroom: A visual conceptualization of teachers' knowledge, goals and beliefs. Journal of Computer Assisted Learning, 25(5), 470-488.

[14]. Chhachhar, A.R., Khushk, G.M. Chachar, A.A \& Qureshi, B. (2013). Internet usage among University students in Pakistan. Journal of Basic and Applied Scientific Research, 3(9), 31-35.

[15]. Collier, S., Weinburgh, M.H. \& Rivera, M. (2004). Infusing technology skills into a teacher education program: Change in students' knowledge about and use of technology. Journal of technology and teacher education, 12(3), 447-467.

[16]. Eady, M. J. \& Lockyer, L. (2013). Tools for learning: technology and teaching strategies', Learning to Teach in the Primary School, Queensland University of Technology, Australia.

[17]. Ertmer, P. A. (2005). Teacher pedagogical beliefs: The final frontier in our quest for technology integration? Educational Technology Research and Development, 53(4), 25-39

[18]. Ghavifekr, S. \& Rosdy, W.A.W. (2015). Teaching and learning with technology: Effectiveness of ICT integration in schools. International Journal of Research in Education and Science (IJRES), 1(2), 175-191.

[19]. Groff, J. (2013). Technology-rich innovative learning environments. Working paper for OECD CERI innovative learning environments project. Retreived on February 4, 2017 from http://www.oecd.org/edu/ceri/Technology-

Rich\%20Innovative\%20Learning\%20

Environments\%20by\%20Jennifer\%20Groff.pdf

[20]. Hennessy, S., Ruthven, K., \& Brindley, S. (2005). Teacher perspectives on integrating ICT into subject teaching: commitments, constrains, caution, and change. Journal of Curriculum Studies, 37(2), 155192.

[21]. Hew, K., \& Brush, T. (2007). Integrating technology into K-12 teaching and learning: Current knowledge gaps and recommendations for future research. Education Technology Research and Development, 55(3), 223-252.

[22]. Hsu, S. (2010). The relationship between teacher's technology integration ability and usage. $J$. Educational Computing Research, 43(3), 309-325.

[23]. Igbo, H. U., \& Imo, N. T. (2017). Electronic Information Resource Sharing among University Libraries in Southern Nigeria: Opportunities and Challenges. African Journal of Library Archives and Information Science, 27(1), 77- 91.

[24]. Jamieson-Proceter, R., Albion, P., Finger, G., Cavanagh, R., Fitzgerald, R., Bond, T., \& Grimbeek, P. (2013). Development of the TTF TPACK Survey Investment. Australian Educational Computing, 27(3), 26-25.

[25]. Kakoty, S., Lal, M. \& Sarma, S. K. (2011). E-learning as a research area: An analytical approach. International Journal of Advanced Computer Science and Applications, 2(9), 144-148.
[26]. Kiran, S. \& Soumen, D. (2018). Role of digital technology in teaching-learning process. IOSR Journal of Humanities and Social Science (IOSRJHSS), 23 (1), 74-79.

[27]. Kitschner, P. \& Davis, N (2003). Pedagogic benchmarks for information and communication technology in teacher education. Technology Pedagogy Educ, 1, 125-147.

[28]. Koehler, M. J., Mishra, P., \& Yahya, K. (2007). Tracing the development of teacher knowledge in a design seminar: Integrating content, pedagogy and technology. Computers \& Education, 49, 740-762.

[29]. Kurz, T. L. \& Middleton, J. A. (2006). Using a functional approach to change preservice teachers' understanding of mathematics software. Journal of Research on Technology in Education, 39(1), 45-65.

[30]. Lonn, S. \& Teasley, S. (2009). Saving time or innovating practice: investigating perceptions and uses of learning management systems. Computers \& Education, 53(3), 686-694.

[31]. Mbangwana, M.A. (2008). Introduction of ICT in Schools and Classrooms in Cameroon. In K. Toure, T.M.S. Tchombe, \& T. Karsenti (Eds.), ICT and Changing Mindsets in Education. Bamenda, Cameroon: Langaa; Bamako, Mali: ERNWACA / ROCARE

[32]. Mishra, P., \& Koehler, M. (2006). Technological pedagogical content knowledge: A framework for integrating technology in teacher knowledge. Teachers College Record, 108(6), 1017-1054.

[33]. Ngajie, B. N. \& Ngo, M. M. C. (2016). Integration of ICTs into the curriculum of Cameroon primary and secondary schools: A review of current status, barriers and proposed strategies for effective Integration. International Journal of Education and Development using Information and Communication Technology (IJEDICT), 12(1), 89-106.

[34]. Nkwenti N. M. (2015). Mastery of Active and Shared Learning Processes for Techno-Pedagogy (MASLEPT): A Model for Teacher Professional Development on Technology Integration. Creative Education, 6, 32-45.

[35]. Nworgu, B.G. (1991). Educational research: Basic issues and methodology: Ibadan: Wisdom.

[36]. Olawale, K. T. (2017). Measuring usability compliance of a stand-alone educational tablet: The users' perspective, Nigeria. Malaysian Online Journal of Educational Technology, 5(3), 25-38.

[37]. Oluwole, C. F. (2018). Pre-service teachers' perceived ease of use, perceived usefulness, attitude and intentions towards virtual laboratory package utilization in teaching and learning of Physics. Malaysian Online Journal of Educational Technology,6(3), 63- 72.

[38]. Puvaneswary, M. \& Yen Siew, H.(2018). Profiling web technology adoption of English language instructors in Malaysian universities. Malaysian Online Journal of Educational Technology.6 (4), 67 82. http://dx.doi.org/10.17220/mojet.2018.04.006 
[39]. Raman, K., \& Yamat, H. (2014). Barriers Teachers face in Integrating ICT during English Lessons 1(3). Malaysian Online Journal of Educational Technology, 2(3), 11-19.

[40]. Robyler, M. D. (2003). Integrating educational technology into teaching (3rd Ed.). New Jersey: Pearson Education, Inc.

[41]. Rowley, J., Dysard, G. \& Arnold, J. (2005). Developing a new technology infusion program for preparing tomorrow's teachers. Journal of Technology and Teacher Education, 13(1), 105-123.

[42]. Schoepp, K. (2005). Barriers to technology integration in a technology-rich environment: Learning and teaching in higher education. Gulf Perspectives, 2(1), 1-24.

[43]. Sekoaila, U., \& Adebesin, F. (2016, May). Women in ICT: Barriers to career advancement and strategies for improvement. In IST-Africa Week Conference, 2016 (pp. 1-12). IEEE.

[44]. Sibusisiwe, D. \& Scott, E. (2017). A survey of the University students' perspectives about using digital technologies in education: Zimbabwean Case. IAFOR Journal of Education, 5(1), 123-139.

[45]. Sottile, J. M. \& Brozik, D. (2004). The Use of Simulations in a Teacher Education Program: The Impact on Student Development. A Critical Review. Hawaii International Conference on Education.

[46]. Staples, A., Pugach, M. C. \& Himes, D. (2005). Rethinking the Technology Integration Challenge: Cases from Tree Urban Elementary Schools. Journal of Research on Technology in Education, 37(3), 285310.

[47]. UNESCO. (2015). ICT in Education in Sub-Saharan Africa, A comparative analysis of basic e - readiness in schools, (25). Retrieved 30th August 2015, from http://uis.unesco.org/sites/default/files/documents/info rmationand-communication technology-ict-ineducation-in-sub-saharan-africa-2015-en.pdf

[48]. Vélez-Agosto, N. M. \& Rivas-Vélez, A. (2018). Benefits and meanings of educating with videogames in a Puerto Rican sixth grade public school classroom. International Journal of Educational Technology, 5(1), 9-19.

[49]. Warwick, P., \& Kershner, R. (2008). Primary teachers' understanding of the interactive whiteboard as a tool for children's collaborative learning and knowledge-building. Learning, Media and Technology, 33(4), 269- 287.

[50]. Wheatley, K. F. (2003). Increasing computer use in early childhood teacher education: The Case of a "computer muddler". Contemporary Issues in Technology and Teacher Education [Online serial], 2(4). Retrieved January 25, 2005 from http://www.citejournal.org/vol2/iss4/general/article1.c $\mathrm{fm}$

[51]. Winzenried, A., Dalgarno, B., \& Tinkler, J. (2010). The interactive whiteboard: A transitional technology supporting diverse teaching practices. Australasian Journal of Educational Technology, 26(4), 534-552.
[52]. Xingeng, D \& Jianxiang, L. (2012). Advantages and Disadvantages of PowerPoint in Lectures to Science Students. I.J. Education and Management Engineering, 9, 61-65. 